\title{
(4)
}

University of New Hampshire

Carsey School of Public Policy

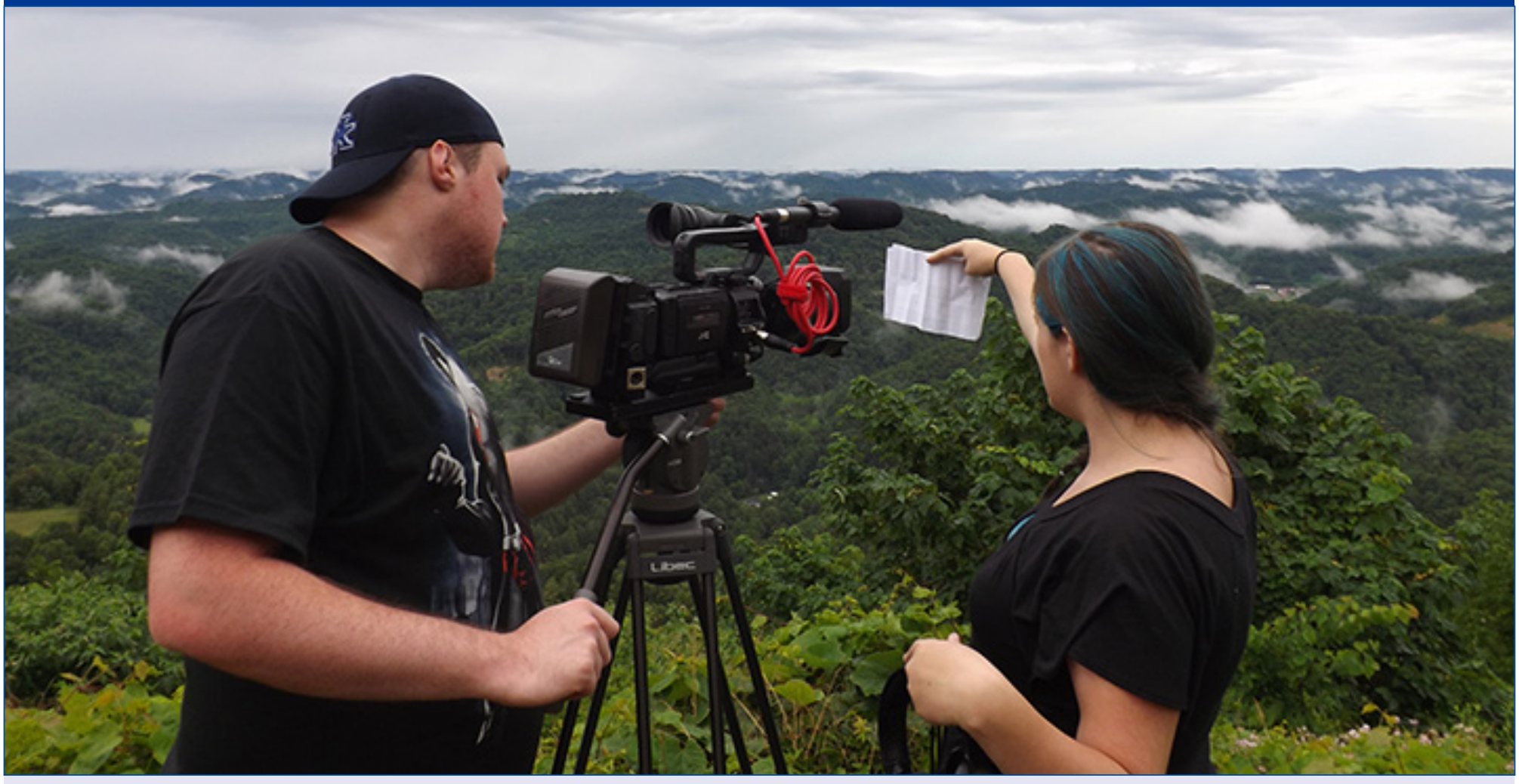

\section{Strategies to Strengthen Youth Leadership and Youth Participation Opportunities in Central Appalachia}

Spring 2015

Rebecca O'Doherty

Ada Smith

Ben Spangler

Elandria Williams

Katie Richards-Schuster 


\section{Introduction}

Appalachia is at an economic crossroads. Coal mining is decreasing as our country increasingly relies on natural gas and other alternative forms of energy. Because of these changes, the Appalachian region has lost thousands of its most high-paying jobs, causing other sectors to suffer-and although these industries are well known for their "boom-bust" cycles, the future of another "boom" for Central Appalachian coal is unlikely. With this economic reality in mind, everyday conversations include the region's future. What kind of economy can be made in Appalachia? What type of future do residents want? How should local governments deal with the lack of appropriate infrastructure and educational institutions given the economic challenges already facing the region? Leadership is essential when considering these questions.

Appalachia is facing a vacuum of new leadership to move forward. Now is the time to specifically develop and encourage youth leadership in the region, inviting young people to sit at decision making tables and allowing them to speak directly to the type of communities in which they want to remain. In Appalachia, critical youth leadership is important but few opportunities and organization spaces exist to help understand and promote its value.

Youth participation is a process of involving young people in the institutions and decisions that affect their lives. It is a process that builds the individual capacities and abilities of youth while contributing to collective community development. The youth participation process in rural communities of Central Appalachia is a unique vehicle for helping young leaders develop the abilities, desire, and vision to move past the barriers with which they are confronted in everyday life. Youth participation includes young people taking initiative and organizing around policy, community building, and social change issues that concern them; youth participation also occurs when adults involve them in proceedings of public and community agencies and institutions-and when youth and adults work together in intergenerational partnerships (Checkoway, 1998; Checkoway \& Richards-Schuster, 2006).
Youth participation, as a field of practice and subject of study, draws on directions in health planning, social policy, community development, and youth development practice; interdisciplinary research in social work, public health, and community planning; and recognition by the United Nations Convention on the Rights of the Child (Checkoway, 1995, 1998; Finn \& Checkoway, 1998; Checkoway \& Richards-Schuster, 2001, 2003; Checkoway et al., 2003; Mullahey et al., 1999; Rajani, 2000).

Although some view young people as problems or victims, a youth participation approach views young people through a lens of citizenship with agency and as contributors to the development and change of their communities and institutions (Finn \& Checkoway, 1998; Finn, 2001; Kurth-Schai, 1988).

Youth participation engages a youth development continuum that distinguishes youth as participants from youth as partners or leaders (Hart, 1997; Pittman \& Fleming, 1991). For this project, we were interested in examining the role of youth as partners or leaders rather than youth as participants in programs. Too often, any activity that engages young people is labeled youth leadership. This distinction fails to capture the potential of actual youth leadership to contribute to positive social change. Youth engagement and youth development activities are an important part of the youth development continuum. However, actual youth leadership requires an intentional focus on developing this leadership using a number of different environments, training, experiences, mentorships, and strategically sequenced learning experiences.

The Central Appalachian region is an ideal location for employing youth participation and youth leadership strategies. Because of the many challenges facing the region, rural communities need young people who are dynamic and who can be entrepreneurial in new approaches to community development and community change. Coupled with this need is the long and diverse history of social action in the region, which informs youth leadership practices with culturally specific practices and assets. Furthermore, youth participation represents a key strategy for building the civic infrastructure needed for leadership and creating sustainable community development necessary to lift communities out of poverty (Richards-Schuster \& O’Doherty, 2012; Fisher \& Smith, 2012). 


\section{Report Purpose and Structure}

The purpose of this study was to assess opportunities for strengthening youth leadership and participation in the Central Appalachian region. In particular, we sought to understand and document the range of activities and strategies in the region as well as understand the nuances involved in promoting and sustaining youth leadership opportunities. Through interviews with key leaders in the region, we explored critical themes for strengthening youth leadership. To highlight the potential and opportunities for future development, we share a case study of an innovative approach to nurturing and sustaining youth leadership. We conclude with a set of recommendations for consideration by policy makers and stakeholders interested in developing sustainable youth leadership practices in Central Appalachia.

The report includes the following sections:

1. Background and Context

2. Approach and Methodology

3. Examining the Region: Exploring Youth Leadership Opportunities

4. Understanding and Assessing Youth Leadership: Key Themes From Interviews

5. Strengthening Youth Participation: A Case Study of the Stay Together Appalachian Youth (STAY) Project

6. Strengthening Youth Leadership in the Region: Recommendations

7. Conclusion

\section{Background and Context}

Youth participation in leadership and organizing in the region stems from the need for resistance and renewal in Appalachian communities. The region has a long history of activism and grassroots organizing. Today, the work of youth is fueled by this legacy of resilience and creativity. The communities of Central Appalachia have long been rich in natural resources, heritage, and culture; however, many of its people are economically poor. Appalachian youth grow up in communities with an average high school completion rate of 68 percent and college completion rate of 7 percent. Roughly 17 percent of the residents live in poverty and youth are disproportionately affected (Appalachian Media Institute, N.D.).
Transnational corporate ownership-and exploitation of the region's natural resources-complicit with local, state, and federal governments has siphoned off the region's wealth and abetted corporate abuse of the land and people. Harlan County, Kentucky, for example, has produced more than 1 billion tons of coal in the past century, yet today it is one of the poorest counties in the nation.

Historically, the energy industry has used various methods to maintain control of the region's towns, stores, schools, doctors, churches, media, and local and state politicians. A deliberate lack of investment in the area has discouraged any meaningful economic development alternatives to the energy industry and has left residents and politicians with a sense of dependency on extraction industries (such as, mining, drilling, and forestry) as the only economic engines. This explicit agenda to separate Appalachian people from the opportunities and tools necessary to participate in governing their communities has contributed to a pattern of chronic poverty, high unemployment, low literacy, lack of essential services, and environmental degradation. Poverty in the region is multilayered and cyclical. Developing positive models of community leadership and social change agencies for a new generation is one pathway to breaking the cycle.

Levels of youth participation have historically followed the patterns of governmental and philanthropic investments on local, state, and national levels. The year 2013 marked the fiftieth anniversary of the War on Poverty, which invested in regional entities such as Appalshop and youth enrichment and literacy programs. Fifty years later, Central Appalachia has made economic gains but still trails the rest of the country. In the 1970s and 1980s, communities responded to destructive and exploitative mining and extraction industries, lack of public health care, and limited opportunities for early and higher education with infrastructure improvements in the form of community centers, civic organizations, head start programs, cooperatives, rural health clinics, workers' unions, Black and Brown Lung Associations, Appalachian studies programs, and more.

Youth leadership development programs and youth organizing groups such as Big Creek People in Action in McDowell County, West Virginia; Direct Action Welfare Group in Charleston, West Virginia; the Young in the Restless Program at the Highlander Research 
and Education Center in New Market, Tennessee; and YouthBuild across the region were born from the energy, resources, and community engagement of the previous decades.

Local governments, state governments, and philanthropic organizations were forced to change funding strategies to meet basic infrastructure needs for the following reasons: (1) the policies of the North American Free Trade Agreement (NAFTA), which drove the few manufacturing jobs in the region to the global South; (2) disinvestment by national philanthropy; (3) push back by coal companies; and (4) the region's elite. At the same time, community change at the grassroots level was devalued. The remnants of these efforts remained from the late 1990s to the early 2000s, but generational corruption, passivity, and communities struggling to meet basic needs created new challenges in participation and investment.

A lack of civic participation and civic infrastructure means communities are struggling to simply articulate and recognize the varied issues in the region, and they lack the resources and systems to begin to resolve these issues. However, the region is rich in environmental and cultural assets, artistic heritage, and kinship support networks-all of which youth can employ in addressing the challenges in their communities (see Fisher, 1993;

Fisher \& Smith, 2012).

Since 2000, civic participation has been revitalized in the region through the fight against mountaintop removal and outmigration - and through the fight for economic and community sustainability. These fights are similar to the fight against strip mining and the fight for community health in the 1970s. Young people are engaged in intergenerational partnerships around food systems, broadband Internet access, alternative energy sources, public education, and an interest in forms of economies that mirror traditional economies such as "mom and pop" businesses, community canneries, and gardens.

When young people are invested in developing wise solutions for the future, their leadership helps their Appalachian communities respond to enormous challenges; thus, their communities not only survive but also thrive. By working with intergenerational partners, youth see how they can be a part of new approaches to the region-the choices are broadened. Youth develop the critical analysis skills to see beyond the challenges and employ asset-based problem solving strategies to persistent community issues. Youth and young adults must become invested as participants, owners, and deciders. This can occur through advisory boards, youth credit unions, and youth philanthropy initiatives-or as an employee learning marketable skills. An investment in young people-and the programs developed for them and by them-must be at the heart of our public budgeting, financing, and community philanthropy.

\section{Approach and Methodology}

This project sought to assess strategies for youth participation and youth leadership in Central Appalachia. Since the beginning, this was a community-based approach, drawing its leadership from the community and engaging a team in the research, analysis, and writing process.

The project involved a three-stage methodology: (1) an initial mapping and examination of youth leadership efforts in the region, (2) identification of key organizations for further examination, and (3) in-depth interviews with key youth and adult leaders to illuminate central themes around youth leadership and to assess issues for strengthening leadership and engagement in the region.

We conducted in-depth interviews with ten young people and adults involved in select efforts. The interviews assessed leadership needs and gaps and explored factors that impact youth leadership in the region and strategies for strengthening youth leadership opportunities in the future.

The interviewees were identified by gathering a list of youth leaders who were active in the region during the last five years, particularly ones who were leading youth programs we had already identified. We then narrowed the list to select interviewees from all of the five target states: West Virginia, Kentucky, Tennessee, Virginia, and North Carolina. When possible, we selected newer leaders and at least one leader who was more established in the organization.

The interviews were conducted by one of the members of the team from the region. Each interview focused on a set of semistructured questions about youth leadership. In particular, we asked the following questions:

- What are some strategies for youth participation and youth leadership at the community level?

- What are the specific strategies youth employ, and what lessons can be learned from them?

- What are the effects of these initiatives on the youth who participate, their organizations, and their communities?

- Who are the youth who participate, and how do they participate? What roles do adults and 
community members play? What are the patterns of participation among young people?

- What are some specific strategies for recruiting and engaging young people in the community?

- What are some organizational structures for sustaining youth participation in Central Appalachia in order to effect the systemic change we need?

- What structures do adults establish for involving young people, and what structures do young people establish on their own?

- What is needed to strengthen youth participation in the region? What are the gaps? What are the policy implications?

Each interview lasted about 50 minutes. Interviews reflected the diversity across the region and were conducted until we achieved a basic saturation of ideas.

We recorded and transcribed interviews for accuracy, and utilized a grounded approach to analyzing the data, looking for patterns and range in the interviews to develop codes. We re-reviewed the data to code quotes and develop the themes. Memos were used to further develop the themes. Drawing on a community-based process, the themes were discussed, analyzed, and checked by members of the team, who represented key partners in youth leadership and community engagement in the region.

Our findings are divided into two sections: (1) an examination of the region and exploratory analysis of youth leadership opportunities and (2) themes from interviews with key informants in the region.

\section{Examining the Region: Exploring Leadership Opportunities}

Our assessment process began with an exploratory examination of the Central Appalachian region to document and capture the range of youth leadership and youth participation programs across Eastern Tennessee, Central Kentucky, West Virginia, and North Carolina (see Table 1). We followed a snowball sample approach beginning with known organizations and foundations as a source for additional recommendations.

While we recognize that this examination was not exhaustive and our approach may have missed some youth leadership opportunities, it was a helpful tool in guiding our inquiry.

\section{TABLE 1. ORGANIZATION LOCATION}

\begin{tabular}{l|c|c|}
\multicolumn{1}{c}{} & TOTAL \# & TOTAL \% \\
\hline CENTRAL KENTUCKY & 10 & 27 \\
\hline NORTH CAROLINA & 3 & 8 \\
\hline EASTERN TENNESSEE & 12 & 32 \\
VIRGINIA & 4 & 11 \\
WEST VIRGINIA & 7 & 19 \\
MULTIPLE & 1 & 3 \\
\hline
\end{tabular}

In this exploratory examination, we found 36 programs that had a focus on youth leadership and development. Of the 36 , we found that the major focus was primarily on civic and environmental issues. Other programs focused on the arts, community development, media and technology, empowerment, firstgeneration college students, and LGBTQ issues. Table 2 shows the findings of the organizations.

\section{TABLE 2. PROGRAM FOCUS}

\begin{tabular}{l|c|c} 
& \multicolumn{1}{c}{ TOTAL \# } & TOTAL \% \\
\hline AGRICULTURE & 1 & 2.8 \\
ARTS & 1 & 2.8 \\
CIVIC & 10 & 27.0 \\
COMMUNITY DEVELOPMENT & 7 & 19.0 \\
EMPOWERMENT OF WOMEN/GIRLS & 2 & 5.5 \\
\hline ENVIRONMENT & 9 & 24.0 \\
FIRST-GENERATION COLLEGE STUDENTS & 1 & 2.8 \\
\hline IMMIGRATION & 1 & 2.8 \\
MEDIA/TECHNOLOGY & 3 & 8.0 \\
\hline TRAINING & 1 & 2.8 \\
LGBTQ YOUTH & 1 & 2.8 \\
\hline
\end{tabular}

Our exploratory examination revealed that many organizations provide programs to and for youth but few promote or engage young people as leaders with a youthled or intergenerational approach (see Table 3).

\section{TABLE 3. ORIENTATION TO YOUTH}

\begin{tabular}{l|c|c|}
\hline \multicolumn{1}{|c}{} & TOTAL \# & TOTAL \% \\
\hline INTERGENERATIONAL & 3 & 8 \\
\hline WELCOMING TO YOUTH & 18 & 49 \\
YOUTH-LED & 4 & 11 \\
YOUTH PROGRAMS & 12 & 32 \\
\hline
\end{tabular}

A "welcoming approach" was found in most organizations, which reflected an organization's willingness to work with young people in some way. "Youth programs" were defined as programs that were directly providing youth activities. "Youth-led" programs reflected organizations that have an explicit 
description of youth leadership, youth staff, or youth roles in their work. "Intergenerational" represented organizations that provide opportunities for youth and adults to work together.

We also found that these organizations are often in partnership with one another through state/regional affiliations or through shared programming, but they are often at a geographic distance from one another-making it potentially difficult for young people to connect. Among these partnered groups are efforts to build networks and create opportunities for young people to link to one another, but many of these opportunities are in the earliest stages of development (see Table 4).

\section{TABLE 4. TYPE OF ORGANIZATION}

\begin{tabular}{l|c|c}
\multicolumn{1}{c|}{} & TOTAL \# & TOTAL \% \\
\hline ADVOCACY & 4 & 11 \\
\hline CIVIC & 9 & 24 \\
INTERMEDIARY & 15 & 41 \\
SCHOOL & 2 & 5 \\
SERVICE & 7 & 19 \\
\hline
\end{tabular}

These opportunities, although in various stages of development, offer promise for what could be created to support and strengthen youth participation and leadership in the Central Appalachian region.

\section{Understanding and Assessing Youth Leadership: Key Themes From Interviews}

To help illuminate the findings, and to study the issues that emerge concerning youth leadership in the region, we conducted in-depth interviews with ten key youth and adult leaders in the region.

In general, the interviewees discussed four critical themes for assessing and understanding youth leadership possibilities:

1. The complexity of involvement for youth and the scarcity of opportunities

2. The importance of adult involvement and the challenges

3. The opportunities and potential for intergenerational work

4. The importance of creating spaces for networking and engagement for youth
Theme No. 1: Complexity of Involvement and Scarcity of Opportunities

Despite the critical realities and issues facing young people in the region, many young people are neither actively engaged in leadership nor working for change. The lack of engagement is because little opportunity for engagement exists-not because of a lack of passion or interest in change.

\section{"Lack of public spaces"}

Often this lack of engagement starts with the inability to connect with communities concerning public issues. One interviewee described this as "a lack of public space in communities." This interviewee added, "So when those get created you have the ability to have conversations, you have the ability to move things forward. We definitely need more spaces where this happens."

Another interviewee stated, "I think for the most part kids feel stuck and feel like there aren't many options. I don't think there are a lot of organizations that are trying to reach out to young people in a meaningful way. What has a much stronger hold on young people is media and consumerism ..."

Although interviewees discussed the lack of public spaces, they also expressed the desire for spaces that are specifically designed for young people to connect with one another. One interviewee took this idea further, stating that such spaces should be designed for and by youth themselves-creating a more inviting and meaningful youth-structured space. Unfortunately, access to resources and financial capacity persist as barriers.

They don't have resources to offer spaces to their friends to come and hang out other than like basements of their parent's house. I don't think young people want to go to places that adults have structured for them.... So, I think spaces for young people to come together need to be developed by those people and they don't have the resources to do so.

Another added, "Having that space for young adults also shows that we don't want to be left out of the policy stuff, like even though it can sometimes get tedious ... we still want to be consulted . . . because we live here, too." 
"There are a lot of issues": The effects of economic and geographical realities on youth

The lack of public spaces for the community, and for youth specifically, is also affected by the challenges and economic realities facing families and the region. These tough realities often lead to disenfranchisement and/or create added obstacles to working for change. As one interviewee elaborated:

I think that young people and older folks alike are really disenfranchised and they have reason to be. There are a lot of issues here and everyone is dealing with a lot of family problems ... there's some specific hurdles to be jumped in getting young people involved ... and not just involved but like dedicated to staying here and working around issues.

The interviewee added:

When you have all these things going on like your family doesn't have money, you don't have money. You can't just sit around on the couch.... You have all these problems and you've got to figure out how to work on you, not the community. So I think there are a lot of obstacles. ... It would be nice to see more young people involved [in rural organizing] but it's not going to happen unless someone makes it a priority because they just don't, they're not knocking down the door, and they're not sitting around waiting.

Another noted the challenge of transportation:

I think that transportation is just a challenge and so what it means to come up and down hills and where things have to be and where things are located. Some things aren't located in relation to areas. They're located really far away from where people are.

Interviewees raised the point that any future leadership trajectories must be tied to economic realities and be linked to employment, stipends, or other sources of income. Some of the interviewees talked about the potential for paid positions:

It's one of the big obstacles that young people don't have funding and they don't have resources to get spaces or get themselves on their feet so that they can think of other things than getting themselves on their feet. I think maybe creating opportunities for like maybe paid positions for young people here.

(Talking about youth): They don't have anything to look forward to. It's not like there is a mass job market. They, you know, go to school ... you're either doing well or you play sports ... so just having a space-that's giving a whole new world of things ...

Others added interesting ideas about microfinancing for projects or finding creative artisan opportunities. However, at least one interviewee noted that, to date, funds have been unavailable for "people who want to get off their feet."

\section{"Ifyou leave, you're a success": Complexity of staying home and working for change}

The challenge of engagement and involvement is also tied to a complex understanding of what constitutes success. Many of the interviewees discussed the notion that success is often tied to leaving home. That is, they are deemed successful if they do not stay involved in the community but leave home for other opportunities. However, if they leave home, they are often viewed as disconnecting and disengaging from the values and beliefs of the community.

As one interviewee stated:

I was raised to believe that if you leave, you're a success, like that's success. Leaving East Kentucky is successful even if you're in Lexington sweeping floors. If you're out of this region, that's how my family thought of it ... but then it's this double-edge sword-if you left you're above your raising. Don't get above your raising and take off. So it's just like this really odd, false-start economy.

Another added:

Young people are more confused now than they've ever been. It's not just here but it's Central Appalachia and other rural places. We're at an economic sadness, so to speak... I think it's a big deal to grow up here and to know that what your grandparents did or what your parents currently do is not what you're going to be able to do. And if it is, you're not going to do it like they did it. 
The implication is that opportunities for leadership must focus on commitment to change in the region while re-envisioning the notion of success. Any efforts to engage and strengthen youth leadership must understand the complexities and realities facing young people in the region (Richards-Schuster \& O'Doherty, 2012). Despite these complexities, youth leadership is critical for the region. As one interviewee noted, "We have to figure out some way to get these folks together and support each other in staying here. That's not happening on any kind of big scale ..."

\section{In-depth focus: Finding ways to link passion - "Creating the} community greenhouse"

This excerpt from one of the interviews shows the importance of helping young people link passions to actions. In this quote, the young person discussed the burnout that has come along with more traditional forms of civic engagement such as writing letters to editors or signing petitions, especially when people feel that those forms of engagement never lead to change. Instead this interviewee wanted to think about other forms of activism that connect to people's passion.

So basically the idea was 'Well, we all really do want to do a lot. Wow, we do have a lot in common, we should keep meeting. Let's start with something small to prove ourselves, that we are able to accomplish something and work from there.' That was something everyone wanted to do, something small and concrete and build from there. I think that was really the key is that people are so tired of larger symbolic gestures, like this is a culture. This is one [of] the things I love most about it, like you do it, put your hand where your mouth is, like make it, don't just talk about it, don't ask someone else to do it for you, don't beg your politician. You want to be able to create it yourself. So we built a greenhouse. And then from there started talking about building a community center and Emily was visiting and realized there was access to this grant and what would people like it to be, and everyone started talking about a kitchen and then a center that could offer all this other stuff. So it really kind of took off, and meetings started picking up, and we ended up having like 20 to 25 people consistently at every meeting, which is really good for here.
So this new community center is kind of a pair with a greenhouse and garden, but the idea is to be ... part of economic development, you could say, reviving the economy as best it can, working with young people - that is one of the key goals of the community center .. . and also just the fancy terms in grants but local building leadership, local leadership, but really just the idea that if someone has an idea they can make it happen and there are people to work with them to make it happen and if you see something you want to do, you can come to this group and say 'I have this really good idea' and there will be people who want to jump on board and work with you. That it would be kind of this like jumping-off point or a place similar to what you were talking about Appalshop.... Um and that from there, anything can happen, once you have a group of people together who are active and see that things can take off and hopefully they will then like that's just creating a healthy structure for any kind of change people want.

\section{Theme No. 2: The Role of Adults-Possibilities for the Future and Challenging Tradition}

A major theme in the interviews was the role of adultsas mentors, supporters, and barriers to the engagement of youth. It is important to understand that adults are critical to re-envisioning the potential for youth leadership, but they also represent one of the major barriers to this vision.

\section{"The elders have a voice."}

The interviewees often linked the barriers and challenges to that of tradition and culture-one in which adults are often viewed as elders and young people are often viewed as children without a voice:

I mean I know when I was younger and I know what I observed of the young people here, until a certain age they don't really see you as a voice at all. They don't recognize you. And it's not in a way that's cruel. It's just that that's the way they talk and what they do ... the elders have the voice.

(Discussing what is needed): Valuing young people, because if you don't actually value them, you aren't going to really care what they think. 
A tradition in which young people are often not expected to have a voice creates complications for building a pipeline for youth leadership and engagement. One person stated:

I do not feel empowered to give my opinion because I'm younger or less experienced.... It's just really intimidating to work on community issues with folks you know are way more experienced than you, especially if you contribute something a couple times and someone says 'we already tried that and it didn't work.' Then you're less likely to contribute because your ideas are kind of shot down.

Another added, "Having people just listen is something that is just not taught, not taught in general to most." Another interviewee noted that dissonance can lead some young people to disengage or "stop pushing" to be involved:

[It's] the combination of Appalachian passivity and the southern hospitality meet, which means you're, you might only push so far even though you should be pushing. People only push so far and they say forget it.

\section{"Hey, this is what we want to do."}

Any future effort to engage young people in leadership and community change needs to focus on strengthening intergenerational partnerships and building the connections between youth and adults. As interviewees noted:

I think it boils down to them just not knowing that young people are interested....

I think young people have to do a better job of letting them know what you want to do because if you don't say it, they're just going to take for granted that you are young and that you are not interested... so it's up to them to seek out young people, but it's up to us if they don't seek us out to say 'hey this is what we want to do, can you make it happen?'

I think that older people have to realize that what is in the present is not in the future.... We can write plans and lay out stuff all day long, but unless it's a success to who it is about or has something to do with who it is about or if they [youth] don't have a voice in it, then we've done nothing but write a bunch of stuff on paper like everyone else. I think there has to be some partnerships, intergenerational to some level.

The last interviewee's optimism showcases the other side of adult engagement with youth in the region. Many interviewees noted the challenges presented by adults who draw on traditional perspectives of youth and do not "hear them" as participants, but there were others who pointed to the role adults have in helping youth engage in community work. They talked about these adults as mentors who saw youth as leaders. According to the interviewees, in order to be connected with community projects, it was important that adults sought out, asked, and engaged youth. For them, they had important adults in their lives who helped them see potential in themselves as leaders.

\section{Being "asked and encouraged"}

One young man talked about getting involved in a community leadership training program because he was "asked and encouraged and had an open mind about trying something I'd never done before ... so it started out with me saying, 'I'm not sure but I'll give it a shot" with the encouragement of various people and then after I figured out that hey, I did it. I survived and I was successful and it made me want to keep doing it."

He continued to discuss his mentor and the role she has played in building his confidence: "She always gets me into things I've never done before but after I've done it, I acquire so many new skills and kind of get the boost of 'I can do this' and the whole self-confidence thing."

\section{Being a role model for others}

The need for self-confidence among youth is another essential element of any strategy promoting youth leadership. Young people need confidence in their own voice and potential, and peer role models can help make that happen:

I think historically that a lot of young people around here just don't have people who think they're worthy of anything ... I actually think it's the young people, who they are, what they want to give or not give, that really molds what other young people want to do and also what staff want to do.

I really had to assert myself in a way that I never expected as an intern to get some changes made... but at the same time, I'm 
also kind of learning from people-so it's kind of a difficult balance between trying to bring new ideas and recognizing that I might have some good ideas, but also from learning from other people and just kind of being a student.

\section{Theme No. 3: Opportunities for Intergenerational Engagement}

Linked to the concept of youth self-confidence is the ability for adults to value young people as contributors. Adults who do not view young people with a role or valuable perspective alienate young people even further from engagement at any level. This is often one of the most essential components of youth leadership being actualized.

For example, interviewees noted, "I think older folks talking to younger folks as their peers and like really asking them what they want and not having a predetermined idea about what they need is probably a good starting point." Discussing what is needed, another said, "Valuing young people, because if you don't actually value them, you aren't going to really care what they think."

These two quotes suggest that genuine intergenerational engagement is lacking. For sharing to take place, youth want to know that their ideas and input are valued. The interviewees provided an important lesson about authentic engagement between adults and youth, facilitated by valuing the role and opinions of young people.

A few of the interviewees described the potential of intergenerational models for building an organizational culture that values the role of youth:

I think if more organizations would take advantage of people ... who do intergenerational teaching and workshops about how to include it in their organizations, then I feel they'll see the value of including young people.

I really value the knowledge of older people and the vivacity of youth-and when we can work together it makes us so much stronger because we all have so much to learn from one another and so much to offer each other. I think young people could do some of this stuff on their own but it will be more fruitful when we work together with older folks.

\section{"Don't want to let up space"}

However, some of the interviewees acknowledged that intergenerational cultures can be a challenge for many long-term social justice organizations:

I think the other part that is just real, is that a lot of these social justice organizations are led by people who founded them.... [That] in its own self is a challenge when young people want to take leadership and they want to get involved, they hit a wall because of the people who've been around forever who don't want to let up space.

I wouldn't be doing this work if I didn't have older people mentor me. I hear older people being very excited-saying we're so excited you're here. We're exhausted. We need you to continue to do this work. ... Of course there's also the issue of older people not be willing to pass the torch to the next generation even though they are saying they want to.

\section{"Seeing potential in young people"}

A common theme in the interviews was that regardless of structure, young people need adults or young adult staff members who can help them visualize their potential and build the skills needed to navigate their leadership within organizations and the region. This type of mentoring can turn emerging leaders into strong, creative decision makers-something needed in a region with a difficult history of exploitation. Ultimately, intergenerational engagement with sincere transparency will be essential for building sustainable leadership pipelines in Appalachia:

Seeing potential in young people to do this kind of community work and engaging those you see who could possibly have an interest and even going after the people who may not show an interest because you never know they just might like it.

I guess giving more skills to the people who are because I would like to see young people create programs instead of it always coming from older people and I guess you do that by giving people skills ... so, I think giving people the full scope of what it takes to do the things that they've been going to and then from there they can start creating their own programs. 
I think the best way to keep something actually sustainable is to get people involved and for people to feel like it is their program, which people feel that way anyway but to take it to the next level.

\section{"Oh I can do this"}

Although adults or younger staff members can nurture and encourage youth leadership, some of the interviewees also discussed the importance of helping showcase youth leadership through peer role models. This model allows inspiration to come from young people themselves in a more comfortable and empowering way:

(In their program): We may give support but they don't see a single adult up in front of them during the youth track parties-only the young people. Which in itself says something 'oh my gosh there's a 14-year-old or a 16-year-old leading me. . ' 'oh I can do this.' So then you have much more energy behind it.... I think that gives people a different sense of what is possible and what it means to take on something and so people can for the next year ... I want to lead this.

I think what's really important is that you always have a young person here having a say in something. I just think that in the end you have to have somebody who really speaks their language. I don't care how many adults you work with, how many youth, how many social economical backgrounds-whatever, you have to have a young person here.

Strengthening youth leadership is a complex issue. One must decide how to support active participation depending on their individual and professional roles. Whether young or old, everyone has a place for leading intergenerational spaces that include everyone's input equally. This type of mutual structure engages Appalachia's needs to reshape its communities.

\section{Theme No. 4: Building Critical Spaces for Youth}

Many of the interviewees discussed the need for a regional leadership initiative-one in which young people come together to discuss issues and develop skills and ideas for implementation.

\section{"A cadre of young people"}

In some ways there needs to be a cadre of young people in each state. They really help to talk about what is going on in our areas, how do we get other people engaged, what's going on. You can say 'here's a core people in all these different places' ... but they are able to come together and have stuff out and study what is ... going on and what do we want to see in our future and for people to like their spaces because there's some stuff you have to do within your own state.

This interviewee went on to talk about the importance of having state gatherings: "I think having state gatherings are important. I think somebody, I think trying to figure out how do you find really key people in each state to be in a state council is really important, or some kind of like council is really important."

Another interviewee noted a similar need for a network for youth:

So we were thinking, how can we connect? But then at the same time there was all these college students and other just people that were real interested in these kind of projects and wanting to get involved and learn from them and how.... That's always the thing, how can you connect in a meaningful way? How can you build a network that actually means something, that you're not just all putting your names on a letter, but you actually have interactions that create something extra? And so we thought, wouldn't it be really exciting to have a group of young people that could work at all the different projects with them?

\section{"Grants for young people": Finding funding for youth-led work}

A few of the interviewees described the need for economic and financial stability to support youth leadership work-through grants for youth-led programs or by funding organizations that support youth leadership and youth-led work:

I think it would almost take young people being elected, or at least being encouraged to run, in positions like that would be a good start. I think the city probably has money 
available to offer grants for young folks, like target it at young folks, building up community, like work on community projects, which I talked about, just offering resources.

In the next five years ... money to be able to pay people to do this work. That's super key. We spend so much time just trying to make ends meet. So few people have jobs that you have to practice living. Paid employees to help people to do this work.

\section{"Hope in the next generation"}

Finally, interviewees discussed a vision for the future that creates a region with organizations that (1) support and welcome youth, (2) bring people together, (3) invest time and energy in the community, and (4) help young people stay in the region.

Show there is hope in the next generation, it is worth investing time and energy in getting to know them and look here are young people that really do care and that kind of boost to the project as well as the boost of just having energy ... building capacity is a useful phrase ... rather than just doing you know, it's something more sustainable rather than giving something and then leaving.

I have this vision to figure out how we help to move all these adult organizations to a different place where they are open and welcoming and loving to young people who enter their doors. If more and more young people start organizing, if more and more young people start changing leadership and ownership, at some point they become grown ...

\section{Strengthening Youth Participation: A Case Study of the Stay Project}

The Stay Together Appalachian Youth (STAY) Project represents one potential approach to strengthening youth participation and leadership in the region. Started by young people for young people, STAY creates spaces for youth to engage, develop leadership skills, and develop projects that enable them to "stay" in the region. This case study explores the history, background, and current status of the STAY Project.

\section{Background}

During a session at the Appalachian Studies Association Conference in 2008, young people expressed that (1) they do not know how to participate in movements for social change, (2) there are few access points for them as young people, and (3) few opportunities exist to develop the skills and knowledge that would allow them to contribute to social change efforts as adults do. Participants in the conference session talked about how self-actualization and taking leadership in their communities were important to them, but they also argued that if you do not have a job, food, clean water, a place to live, or good health care, then self-actualization is not possible. A handful of the youth continued to talk about the experience and envisioned what became the STAY Project.

The STAY Project is a regionally-focused, youth-led grassroots organization seeking to provide critical education and leadership training that will help future Appalachian leaders find environmentally and economically sustainable ways to participate and remain in their communities. Since the first meeting in 2009, the STAY Project has engaged and empowered emerging young leaders (ages 14-30), in Eastern Tennessee and Kentucky, Southwest Virginia, western North Carolina, and all of West Virginia-areas that have seen an exodus of young people owing to, among other factors, the lack of economic and educational opportunities. As young people in the area deal with issues such as poverty, teenage pregnancy, struggling schools, drug addiction, and job scarcity, they need support and opportunities that allow them to stay in the area in order to more effectively address these problems. In addition, youth of color and LGBTQ youth are under-represented in the region's organizations and communities, meaning targeted programs for these often ignored communities are essential to sustaining a diverse region.

Although STAY is completely youth-led, several organizations drafted the project. The Highlander Research and Education Center, Appalshop's Appalachian Media Institute, and the High Rocks Education Corporation offered support and financial assistance in the project's early years. Many of the adults in the initial organizations then (1) offered advice on STAY's first grants and fiscal sponsorship, (2) connected youth leaders to other regional organizations working with youth, and (3) offered space, 
lodging, and travel assistance that made the first events possible. These organizations still offer guidance when requested but are no longer a part of any decision making because the need for youth leadership in Central Appalachia is increasingly important.

One of the distinctions of STAY is moving to a new level of youth leadership. Many of the early STAY organizers and founders were already in youth development programs hosted in adult-led institutions, some of which exclusively did youth engagement work and some of which had one or two youth programs as part of their larger organizational work; therefore, many of the STAY organizers and founders had been through a "youth development" or initial "youth leadership development" process. However, after moving through these programs, young people needed support and training to transition into positions of increased authority and responsibility in order to run campaigns, organizations, and programs on their own. Young people needed more intentional and authentic opportunities to engage in leadership that affected other youth, their organizations, and the community - and that is the purpose of STAY.

As our country continues to urbanize, those who live in mostly rural regions such as Central Appalachia have a greater need to create regional access points for rural youth to participate in local and national conversations. Central Appalachia, in particular, is in the middle of economic transition as the country explores new forms of energy-moving from coal to a natural gas-based economy. These struggles force communities to have larger conversations about political leadership, supportive infrastructure, and quality of life that affect long-term sustainability. The STAY Project wants to be present in this conversation by expressing the unique needs and perspectives of young people to our region's leaders and the nation.

\section{Overview of STAY}

Throughout the South and Appalachia, many organizations provide direct services to youth or gather them to participate in community activities. In contrast, the STAY Project asks young people to be the decision makers, to design their own projects, and to contribute solutions to community needs.

The STAY Project implements its mission by:

1. providing vehicles for and encouraging youth to articulate their own problems and ideas for community change to one another
2. educating youth leaders and connecting those leaders with opportunities for real responsibility and action through training, organizational fellowships, and leadership gatherings

3. recognizing young leaders in the region who are already creating solutions

4. creating regional systematic change

STAY Project leaders articulate their work in this way:

The STAY Project is about the need for communities now and in the future to have the basic human rights that everyone deserves, no matter where they live, their economic background, their race, language, religion, sexual orientation, gender identity, or cultural background. It is crucial to provide more spaces for people to gather formally and informally because there are few regional networks, meeting places, spaces for intergenerational conversation, or united youth visions in Central Appalachia. The STAY Project's network of members and regional gatherings creates avenues for our communities to educate themselves, find voice, and nurture political power.

\section{Effects to Date}

In the past five years, STAY has (1) built a membership base of more than 150 members in the five Central Appalachian states, (2) held three multiday Summer Institutes, and (3) hosted LGBTQ youth and youth of color gatherings. All members are included in the governance of STAY through its annual membership meeting at the Summer Institute where leadership and strategy are determined. Members analyze the condition of the region, determine how to work on leading issues, and suggest networking activities to boost effectiveness. In addition, members help nominate and elect a seven-person steering committee. These committee members represent identity and geographic diversity while leading core program work, particularly when staff are absent.

The STAY Project has recently launched memberled working groups to focus on public education, clean water, and juvenile justice. These issues were selected collectively and focus on shifting institutions. Basic infrastructure needs are vital for young people who are growing up in rural, impoverished 
communities and who wish to make a life in these communities. STAY members have chosen public education, clean water, and juvenile justice as pathways to begin demanding basic rights without bias so that their communities can thrive. For instance, access to clean water has become an increasing problem for most residents in the region owing to the lack of sewage systems and the presence of toxic waste from extractive industries such as coal. Young people in these communities offer a unique perspective on why clean water should be a priority so that they may remain in their homes in the region. STAY's work is informed by members who are individuals rooted in their communities. These individuals are young people who want to learn new skills, make alliances, deal with personal struggles, and engage in organizational and community leadership roles.

\section{Future Directions}

During the past five years, STAY has operated without paid staff. Future directions for STAY include securing funding to hire a full-time coordinator and building the organizational infrastructure to sustain the work. With this capacity added, STAY can begin to move from an informal network and training project into a full-fledged voice for regional change. Network members are eager to begin state cohorts, policy fellowships, and an active communications system that could change the region's view of youth participation.

\section{Strengthening Youth Leadership in the Region: Recommendations}

The purpose of this project was to assess youth leadership and to explore possibilities for strengthening youth leadership in the Appalachian region. On the basis of our examination of the region and interviews, we propose the following recommendations for policy makers and practitioners interested in building youth leadership in Central Appalachia.

\section{More Organizations That Support Youth Leadership}

Developing programs that promote youth leaders and opportunities for youth is needed. A growing number of organizations focus on youth work, but very few engage young people as leaders or organizers. Although welcoming organizations are very important, developing leadership opportunities for youth is vital.
Strong anchor organizations in the region are doing important work in moving the region forward toward greater economic and social justice. These organizations should make it a core program goal to train youth leaders in their areas of expertise: economic development, media and communications policy, environmental justice and policy, and legal justice. In addition, these organizations should integrate trained youth into their organizations to act as leaders.

Furthermore, young people want to help create the programs and organizations that support youth leadership. Community-based philanthropy with a focus on (1) youth leaders, (2) funds for youth-initiated activities, and (3) incubator programs for project development within existing institutions and organizations could help involve youth.

Finally, policy should increase funds and resources devoted to youth development-particularly youth leadership - at the local, state, regional, and national levels. With the input of youth stakeholders, policies should be revised to support youth as leaders.

\section{Creating Leadership Pipelines}

As Appalachia contends with an uncertain future, the need for leadership pipelines grows. There must be opportunities for youth to engage mentors, create spaces for conversations concerning critical issues, and provide long-term leadership in the region. This type of leadership development is important because it allows youth to successfully transition into advanced leadership positions in organizations and institutions. Although youthfriendly programs exist throughout the region, regional leadership pipelines that cultivate the type of creative, solution-driven results Appalachia needs are lacking.

Difficulties arise between training youth leadership and situations with real outcomes. One way to bridge this gap is purposefully creating more opportunities for youth to lead in decision making and policy-making bodies within government and public institutions in the region. These institutions include planning commissions, school boards, local municipal governments, economic development positions, regional commissions, and nonprofit service and cultural organizations.

Youth also need specialized, advanced training beyond what they receive in school or higher education institutions to prepare them to contribute to decision making and policy-making bodies. Without intensive skill development, youth will have difficulty realizing their visions for positive change. 


\section{Opportunities That Link Civic Engagement and Economic Development}

Young people complexly describe the notion of leaving and staying. On one hand, young people believe that to be successful they need to leave, and on the other hand, they have a deep desire to stay and continue to build the region. Focus should be placed on providing opportunities for young people to contribute to the leadership of the region and to economic development-individually and regionally. Strategies might include small business development in the form of microloans, community loans, and loans to support local businesses developed by and for younger people. Small business development could be accomplished within specialized entrepreneurial settings such as at community colleges and area universities, or by linking youth with accomplished entrepreneurs who mentor youth-led businesses and organizations. Studies could assess the successes of microlending in Appalachian economies with young entrepreneurs.

Opportunities for skill development are also needed in order to help young people see the links between leadership and economic development. Young leaders need more accessible links to available resources, education and training for grant and loan applications, and spaces for regional networking around issues of economic development and regional business. Youth should also receive training necessary to succeed as small business owners and organization directors. At a time when the region is at a crossroads, youth need opportunities to help shape the direction of the economy more than ever before.

\section{Focus on Creative Opportunities}

One possibility for linking youth leadership and regional development is through arts and creative, cultural-based programming. As the region seeks to strengthen leadership, young people need opportunities to engage and become involved with organizations and begin to develop the skills that are critical for building youth leadership. Many of the interviewees mentioned the importance of the arts-both traditional and contemporary-for engagement and development. Arts- and music-based classes, critical media programs, and spaces that encourage creativity are vital for young people. Creativity is an outlet for examining ideas, discussing issues, and developing new approaches for the region. Creative spaces also provide opportunities to link community and leadership engagement with economic and regional vitality.

\section{Building Capacity of Adults}

Although youth leadership and capacity development are critical, so is the need to build the skills and capacities for adults to work with youth. Any effort on strengthening youth leadership and engagement must also focus on the adults who work with and connect with young people. Examples include the following: (1) programs for adults and traditionally adultoriented organizations that teach adults to work with young people, (2) education and training on issues of youth leadership and youth civic development, (3) networking and support for adults working with young people in leadership, and (4) funding to support staff positions focused solely on nurturing and engaging youth within organizations. In order to see themselves as leaders, many young people need adults who understand youth as competent citizens with a future in building and shaping the region. Lacking opportunities for adults to build their skills in this work, it will be difficult to sustain a broad youth leadership initiative in the region.

\section{Believing in the Potential of Youth: Various Approaches}

Programs are needed to help young people recognize their own potential in a region where they have not always been seen as leaders. Because of the lack of youth leadership, and the civic participation that would precede this more advanced engagement, we suggest multiple approaches to help young people connect to the community as a first step toward leadership.

As mentioned earlier, arts and cultural spaces provide one avenue for engagement. Other opportunities include service or sport opportunities that could be connected to leadership development and civic engagement. Possibilities exist in a number of venues: schools, community colleges, area universities, community organizations, local government-sponsored placements, the juvenile justice system, partnerships with faith-based organizations, and others.

Multiple avenues for participation are also important because, in addition to the strong history of activism and resistance in the region, conditions continue to necessitate social action. Suppression of democratic engagement and the free exchange of ideas can intimidate youth from civic participation. Youth must also be given opportunities to find their own interests and passions in civic engagement. 
Often this occurs through programs in which youth develop their own knowledge in collaboration with their peers and other community members.

Regardless of the approach, young people need to believe in their own potential and to see that the activities they engage in as youth translate into longterm leadership and engagement in their communities and in the region. When young people engage in real work that has real consequences for the region, they have a visceral understanding of the outcomes of their efforts. This immediate feedback deepens and sustains their engagement, propelling them forward to try new and more daring work.

\section{Building Infrastructure of Economy and Transportation-Creating Vibrant Communities for Youth}

Participation is often limited by the (1) lack of spaces for young people to be creative, (2) lack of funding to support youth leadership, and (3) challenges shaped by the historic and economic roots of Appalachia. As local areas begin to re-engage with community development caused by a larger economic transition, it is vital to highlight the need for infrastructure that encourages young people to thrive in their communities.

Vibrant, inclusive public space is critical for the survival of Appalachian communities, and consideration is particularly needed for transportation if young people are to actually reach these spaces. The young leaders we have spoken with for this report see revitalization of and investment in the region's public transportation infrastructure as key to keeping rural, Appalachian communities alive.

Youth leadership development programs must also consider how to support young people as they go through intensive training programs or spend hours after school or during the summer in leadership roles. Many youth leaders, although making significant contributions to the public good, struggle with food and housing security; do not have regular access to a car or public transit; contribute to their family income while still in highschool and after graduation; have limited health care access; and may benefit from emotional support services. Successful youth leadership development programs may need to plan for transportation and financial compensation-and support for other services-to make participation possible. Some effective approaches we have seen included offering training and activities within apprentice- and employment-based structures.

\section{Conclusion}

The purpose of this study was to assess opportunities for strengthening youth leadership and participation in the Central Appalachian region. In particular, we sought to understand and document the range of activities and strategies in the region and to understand the nuances involved in promoting and sustaining youth leadership opportunities.

Based on our work, we believe that this is a critical time for Central Appalachia to understand and promote emerging leadership while receiving outside support to actualize the leadership infrastructure needed. Specifically, the link between regional development and youth participation provides an exciting space for potential and economic promise.

Appalachia has an incredible history of grassrootsled change. The region can be open to change if young citizens are allowed to play active roles in visioning and planning the future. 


\section{References}

Appalachian Media Institute. Program Materials. Appalshop: Whitesbury, KY (www.appalshop.org/ami).

B. Checkoway et al., "Youth Participation in Community Planning: What Are the Benefits?" Journal of Planning Education and Research, vol. 14, no. 2 (1995): 134-139.

B. Checkoway, "Involving Young People in Neighborhood Development," Children and Youth Services Review, vol. 20 (1998): 765-795.

B. Checkoway and K. Richards-Schuster, "Lifting New Voices for Socially Just Communities," Community Youth Development, vol. 2 (2001): 32-37.

B. Checkoway et al., "Young People as Competent Citizens," Community Development Journal, vol. 28 (2003): 298-309.

B. Checkoway and K. Richards-Schuster, "Youth Participation in Community Evaluation Research," American Journal of Evaluation, vol. 24 (2003): 21-33.

B. Checkoway and K. Richards-Schuster, "Youth Participation for Educational Reform in Low-Income Communities of Color." In Beyond Resistance: Youth Activism and Community Change: New Democratic Possibilities for Policy and Practice for America's Youth, edited by P. Noguera, S. Ginwright, and J. Cammarota (New York: Routledge, 2006).

J. L. Finn and B. Checkoway, "Young People as Competent Community Builders: A Challenge to Social Work," Social Work, vol. 43 (1998): 335-345.

J. L. Finn, “Text and Turbulence: Representing Adolescence as Pathology in the Human Services," Childhood, vol. 8

(2001): 167-192.

S. Fisher (ed.), Fighting Back in Appalachia: Traditions of Resistance and Change (Philadelphia, PA: Temple University Press, 1993).

S. Fisher and B. Smith, The Struggle for Appalachia: Identity, Place and Movement-Building (Champaign-Urbana, IL: University of Illinois Press, 2012).

R. Hart, Children's Participation: The Theory and Practice of Involving Young Citizens in Community Development and Environmental Care (London: Earthscan, 1997).

R. Kurth-Schai, “The Roles of Youth in Society: A Reconceptualization," The Educational Forum, vol. 53 (1988): 113-132.

R. Mullahey, Y. Susskind, and B. Checkoway, "Youth Participation in Community Planning” (Chicago, IL: American Planning Association, 1999).

K. J. Pittman and W. E. Fleming, "A New Vision: Promoting Youth Development" (Washington, DC: Center for Youth Development and Policy Research, Academy for Educational Development, 1991).
R. Rajani, “The Case for Youth Participation.” Unpublished paper (2000).

K. Richards-Schuster and R. O’Doherty, “Staying Home: Appalachian Youth Re-envision Their Identities, Reconstruct Community and Take Action." In The Struggle for Appalachia: Identity, Place and Movement-Building, edited by S. Fisher and B. Smith (Champaign-Urbana, IL: University of Illinois Press, 2012), pp. 78-91.

Stay Together Appalachian Youth (STAY) Project Proposal and Program Documents.

\section{About the Authors}

Ada Smith is the institutional development director at Appalshop, central Appalachia's anchor cultural institution, located in Whitesburg, Kentucky (ada@appalshop.org).

Ben Spangler is the director of the Appalachian Media Institute, Appalshop's youth media program that is dedicated to developing the leadership, civic engagement, and personal potential of Appalachian youth (bens@appalshop.org).

Elandria Williams is education team co-coordinator at the Highlander Education and Research Center in Tennessee (elandria@highlandercenter.org).

Katie Richards-Schuster is an assistant professor at the University of Michigan School of Social Work (kers@ umich.edu).

Rebecca O'Doherty is a past director of the Appalachian Media Institute at Appalshop (rebeccaod@gmail.com).

\section{A cknow led g ments}

The authors would like to thank Dr. Curt Grimm and the Nancy Nye Fellowship for their support for this project. We would like to thank the individuals and organizations that lent their voice through interviews. Finally, special thanks to Catherine Distelrath for her assistance with the report. 


\section{TI University of New Hampshire \\ Carsey School of Public Policy}

The Carsey School of Public Policy conducts policy research on vulnerable children, youth, and families and on sustainable community development. We give policy makers and practitioners timely, independent resources to effect change in their communities.

This work was supported by the Rural Local Initiatives Support Corporation (“LISC”), Nancy Nye Fellowship Program.

Huddleston Hall • 73 Main Street • Durham, NH 03824

(603) 862-2821

TTY USERS: DIAL 7-1-1 OR 1-800-735-2964 (RELAY N.H.)

carsey.unh.edu 